\title{
A new species group and two new species of freyine jumping spiders (Araneae, Salticidae, Aelurillini)
}

\author{
Gonzalo D. RUBIO ${ }^{*}$, María F. NADAL ${ }^{2}$, Julián E. BAIGORRIA ${ }^{3}$, Luciana I. OKLANDER ${ }^{4} \&$ \\ G. B. EDWARDS ${ }^{5}$
}

\begin{abstract}
${ }^{1}$ CONICET, Estación Experimental Agropecuaria Cerro Azul (EEACA, INTA), Cerro Azul, Misiones, Argentina ${ }^{2}$ Laboratorio de Biología de los Artrópodos, Universidad Nacional del Nordeste (FaCENA, UNNE), Corrientes, Argentina. ${ }^{3}$ Fundación de Historia Natural Félix de Azara (FHNFA), Buenos Aires, Argentina. ${ }^{4}$ CONICET, Instituto de Biología Subtropical, Universidad Nacional de Misiones (IBS, UNaM), Puerto Iguazú, Misiones, Argentina. ${ }^{5}$ Florida State Collection of Arthropods, Division of Plant Industry, Gainesville, Florida, USA.

*Correspondence: E-mail: grubio@conicet.gov.ar
\end{abstract}

\begin{abstract}
Wedoquella apnnea sp. nov. and W. karadya sp. nov., two new species of the jumping spider subtribe Freyina are described and illustrated from specimens recently collected in Misiones and Chaco provinces, Northeastern Argentina. The new species are placed into a new group of Wedoquella because, although in body morphology they resemble the Phiale gratiosa group, the genital structures of both sexes more closely resemble those of Wedoquella, and a preliminary analysis based on mitochondrial COI sequences places this new group as sister to Wedoquella rather than to Phiale. Both new species are similar, but can be distinguished mainly by differences in the retrolateral tibial apophysis of the male palp. Females have a slight intraspecific color variation.
\end{abstract}

Key words: Neotropical spiders, Wedoquella, taxonomy, COI sequences, Phiale.

Resumen: Un grupo nuevo de especies y dos especies nuevas de arañas saltarinas freyinas (Araneae, Salticidae, Aelurillini). Wedoquella apnnea sp. nov. y W. karadya sp. nov., son descriptas e ilustradas a partir de especímenes colectados recientemente en las provincias de Misiones y Chaco, Nordeste de Argentina. Las nuevas especies se asemejan morfológicamente a las del grupo gratiosa de Phiale, sin embargo, son colocadas dentro de un nuevo grupo de Wedoquella debido a que las estructuras reproductoras de ambos sexos se asemejan más estrechamente a las de éste género, y un análisis preliminar basado en secuencias mitocondriales de COI ubica a este nuevo grupo como hermano de Wedoquella en lugar de Phiale. Ambas especies nuevas son similares, pero pueden distinguirse principalmente por diferencias en la apófisis retrolateral tibial del palpo masculino. Las hembras tienen una ligera variación intraespecífica de color.

Palabras clave: Arañas neotropicales, Wedoquella, taxonomía, secuencias de COI, Phiale.

\section{INTRODUCTION}

The jumping spider genus Wedoquella (family Salticidae) was created by Galiano (1984) and currently constitutes one of the least diverse of the twenty genera of its subtribe (Edwards 2015). Wedoquella comprises three known species that have a narrow distribution in South American (Metzner 2019; World Spider Catalog 2019). The species that constitute this genus have been studied by Galiano for almost twenty years. The general appearance, the color pattern and the chaetotaxy are very similar to those of Phiale C. L. Koch, 1846, and for some time, it was thought that they were other Phiale species (Galiano 1984).
Together with Phiale, Wedoquella belongs to the Neotropical subtribe Freyina, one of the three subtribes of the tribe Aelurillini (including the widespread Old World Aelurillina and the African Thiratoscirtina). The freyines differ from aelurillines by lacking a pocket on the cymbium, and often have the carapace marked by longitudinal bands of white or pale scales, which consist of a median stripe and a lateral band on each side below the lateral eyes (Maddison 2015). Freyina also differs from Aelurillina and Thiratoscirtina by its general habitat preference, as most Thiratoscirtina and Aelurillina are ground-dwelling (Maddison 2015), while most Freyina are foliagedwelling. Many species of freyines probably mimic ants and/or mutillid wasps (Edwards 2015). 
In this contribution we describe two new species of Wedoquella from Argentina in a new species group. In addition, we present a small preliminary analysis based on mitochondrial COI sequences to explore the conspecificity of these two species, and a first approach of the relationship between these and some close relatives.

\section{MATERIALS AND METHODS}

\section{Taxonomy}

Morphological terms, abbreviations, definitions, and some measurements follow the main recent study on freyines (Edwards 2015). Female genitalia were dissected as in Levi (1965), examined after digestion in hot $\sim 15 \% \mathrm{NaOH}$ solution and cleared in clove oil to examine the internal structures. Expansion and clearing of the male palps were done by placing the palps in a $\sim 15 \%$ $\mathrm{NaOH}$ solution and then transferring them to distilled water. Temporary preparations were observed and photographed using a Leica DM500 compound microscope and a Leica M60 stereomicroscope. Structures were sketched from incident light photograph models using a computer system for drawing and treatment of the image (Wacom digitizer tablet with GIMP, free software). Measurements were taken directly from a microscope ocular lens with ocular micrometer and are expressed in millimeters. Photographs of live spiders were taken using a Nikon D80 digital camera with a Micro-Nikkor $85 \mathrm{~mm}$ lens (except photo in Figure 1D taken with a pocket camera). Availability of data and materials. Canadian Centre for DNA Barcoding (CCDB) produced the sequences in the study. Sequences generated are available in BOLD and GenBank; voucher specimens were deposited in the collection of the Instituto de Biología Subtropical, Misiones, Argentina (IBSI-Ara).

\section{Mitochondrial DNA analysis}

One leg of each type specimen (indicated in the text as "tiss.s.") was used for extraction of DNA following a glass fiber-based extraction protocol (Ivanova et al. 2006), and was also deposited at the IBSI-Ara collection.

A 658-bp fragment near the $5^{\prime}$ end of the COI gene was amplified following standard protocols developed for DNA barcoding (Wilson 2012) using primers C_LepFolF/C_LepFolR (Folmer et al. 1994) in the Barcoding laboratory in the Museo Argentino de Ciencias Naturales (Buenos Aires), sequenced in the Canadian Centre for DNA Barcoding (CCDB), Ontario. The sequenc- es were edited using Chromas 2.6.5 (https:// technelysium.com.au/wp/chromas/) and aligned using and MUSCLE algorithm (Edgar 2004) in MEGA X (Kumar et al. 2018). Sequences with stop codons were excluded. We inferred the evolutionary history tree using MEGA X and the Neighbor-Joining method (Saitou \& Nei 1987). The bootstrap consensus tree inferred was made with 10000 replicates (Felsenstein 1985). The evolutionary distances were computed using the Kimura 2-parameter method (Kimura 1980) and are in the units of the number of base substitutions per site. We also inferred the evolutionary history using the Maximum Likelihood method and Tamura-Nei model (Tamura \& Nei 1993) with 1000 rapid bootstrap pseudoreplicates. The tree with the highest log likelihood (-2730.03) is shown. The percentage of trees in which the associated taxa clustered together is shown next to the branches. Initial tree(s) for the heuristic search were obtained automatically by applying Neighbor-Join and BioNJ algorithms to a matrix of pairwise distances estimated using the Maximum Composite Likelihood (MCL) approach, and then selecting the topology with superior log likelihood value. The tree is drawn to scale, with branch lengths measured in the number of substitutions per site.

These analyses involved 12 nucleotide sequences. We included one specimen of the genus Phiale, one of Pachomius Peckham \& Peckham, 1896 and three from the genus Wedoquella for a better understanding of the phylogenetic position of these two new species within the subtribe Freyina. For the construction of the outgroup, we tested two alternatives: first other spiders from the genus Synemosyna Hentz, 1846 and Sarinda Peckham \& Peckham, 1892 from the tribes Simonellini and Sarindini, and second with Maeota Simon, 1901, Marma Simon, 1902 and Coryphasia Simon, 1902 from the tribe Euophryini. The results were identical with both, and for practical purposes, we show only the first one.

\section{Abbreviations}

$\mathrm{CD}$, copulatory duct; $\mathrm{CO}$, copulatory opening; $\mathrm{Cy}$, cymbium; EB, embolus base; FD, fertilization duct; $\mathrm{Fu}$, fundus; MEeb, membranous edge of embolic base; pCP, posteriorly-opening coupling pocket; RTA, retrolateral tibial apophysis; $\mathrm{S}$, spermophore; Sp, spermatheca; TBD, tegulum basal division; TDD, tegulum distal division. 


\section{SYSTEMATICS}

Family SALTICIDAE Blackwall, 1841

Subfamily SALTICINAE Blackwall, 1841

Tribe AELURILLINI Simon, 1901

Subtribe FREYINA Edwards, 2015

Genus Wedoquella Galiano, 1984

Remarks. The generic diagnosis for differentiation of Wedoquella is well defined by Edwards (2015). The species described here conform to it, however, do not belong to the extant group of Wedoquella, nor seem to fit into any of the proposed groups of Phiale (gratiosa, mimica or formosa). The presence of a short straight embolus and a partially membranous embolus base appears to place both new species in a different group of Wedoquella, designated here as apnnea group (new).

\section{Wedoquella apnnea Rubio, Nadal \& Edwards, sp. nov. \\ (Figs. 1A-C; 2A-C; 3)}

Type material. Male holotype (IBSI-Ara 0849; tiss.s. 0849) from Argentina, Chaco: Capitán Solari, Parque Nacional Chaco (S26.80724ㄴ, W59.607988 $)$, 24 October 2016, G.D. Rubio \& E.I. Meza-Torres coll. Female paratype (IBSI-Ara 0873; tiss.s. 0873) from same Parque Nacional Chaco, "Quebracho" forest (S26.812327", W59.626823), 07 November 2016, G.D. Rubio, M.F. Nadal, G. Avalos, I. Zanone \& P. González coll.

Etymology. The specific name is a noun in apposition derived from the initials of the "Administración de Parques Nacionales" (APN) and the Northeastern region of it and Argentina (NEA).

Diagnosis. Specimens of $W$. apnnea are very similar to those of $W$. karadya by having a short, straight embolus associated with a small membrane (MEeb) connected with the embolus base (Figs. 2A, H; 3C; 4D); and by having eggplant-shaped spermathecae, not spherical (Figs. 2C, E; 3F, G; 4J). They also lack the more dorsal RTA of other Wedoquella. Male of W. apnnea can be easily distinguished from that of W. karadya by having a finger-shaped RTA, with a thin base (Fig. 3B, D), and a conspicuous EB with small membranous area (MEeb) (Figs. 2A; 3C). Female of $W$. apnnea is distinguished from W. karadya by having wider and shallower pCP, and spermathecae slightly more separated to each other (Figs. 2B, C; compare with 2D, E).
Description. Illustrated in figures 1A, B; 2A; 3A-D: male (holotype): total length: 10.00 . Carapace length: 5.00; width: 3.95. Carapace dark brown, with a dorsal median white stripe and wide white marginal bands; cephalic region darker, with scattered blackerectsetae. Chelicerae dark brown, with two teeth on promargin and one tooth on retromargin. Sternum dark brown, with abundant scattered long white hairs. Legs stout, hairy, ringed with light and dark hairs. Abdomen length: 4.90; width: 3.80; coloration black in the anterior half and red in the posterior half (somewhat discolored by alcohol), with a dorsal median white stripe and wide white lateral bands; abdomen with scattered black erect setae on the dorsum. Live specimens have the eyes bordered by red scales, and the general coloration is strongly black, white and red. Palp: femur stout, tibia wider than long with conspicuous finger-shaped RTA, with a thin base, and more sclerotized apically. Embolus short, straight, well-sclerotized, associated with a small membrane on the distal prolateral edge of a conspicuous embolus base. Cymbium with a proximal dorsal projection similar to Philira Edwards, 2015, but more elongated.

Female (paratype) illustrated in figures 1C; $2 B$, C; 3E-H: total length: 9.90. Carapace length: 4.80; width: 3.80. Carapace brown; thoracic region less dark than cephalic region (in alcohol), with scattered black erect setae. Chelicerae light brown, yellowish, with two teeth on promargin and one tooth on retromargin (as in Figure 2F). Sternum brown, with abundant scattered long white hairs. Legs brown, stout and hairy. Abdomen length: 5.00; width: 3.50; dorsal coloration reddish brown with four paramedial white spots and several lateral irregular white spots, all white spots edged in black. Abdomen with scattered black erect setae on the dorsum (shorter than in male). Live specimens with strongly contrasting coloration. Epigyne: epigynal plate conspicuous, sclerotized; with two anterolateral copulatory openings, shaped like semicircular grooves; copulatory ducts short, not coiled, connecting to eggplant-shaped spermathecae; fertilization duct anterior to spermatheca.

Natural history. Specimens from Parque Nacional Chaco were collected from the foliage of a woodland dominated by Schinopsis balansae Engl. ("Quebrachal"); specimens from Misiones were found in an abandoned tea crop (Camellia sinensis (L.) Kuntze).

Distribution. Known from the type locality in Chaco province, and Cerro Azul, Misiones. 

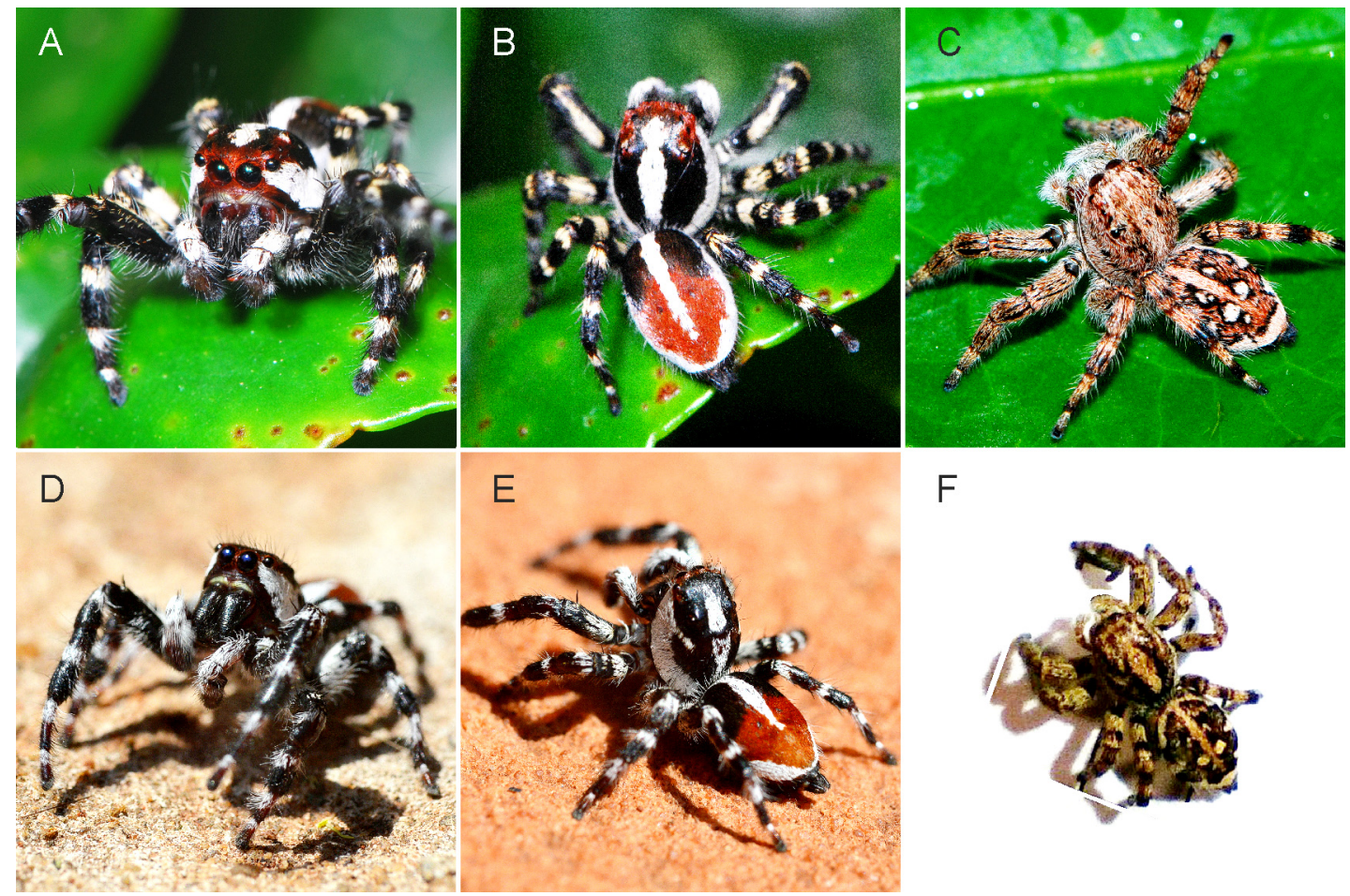

$\mathrm{F}$

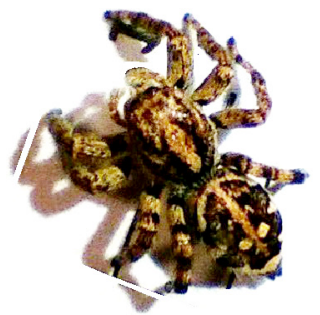

Fig. 1. Habitus in nature. Male (A, B) and female (C) of Wedoquella apnnea sp. nov., and male (D, E) and female (F) of W. karadya sp. nov. Specimens from Chaco in the three upper photos, from Misiones in the lower three.

Other material examined. 1 male (IBSIAra 1160) from Misiones: Leandro N. Alem, Estación Experimental Agropecuaria Cerro Azul $\left(\mathrm{S} 27.656^{\circ}, \mathrm{W} 55.446^{\circ}\right), 29$ October 2018, G. Anunciación \& J. Ocampo coll.; 1 male (IBSI-Ara 1161), same locality and date, C.E. Stolar coll.; 1 male and 1 female (IBSI-Ara 1163), same locality, 30 October 2018, G.D. Rubio \& C.E. Stolar coll.; 1 male (IBSI-Ara 1164), same data.

Barcode. Nucleotide sequence of COI-5P of male holotype, process ID IBSAR063-17:

AACTTTATATTTAATTTTTGGAGCTTGATCT GCTATAGTTGGAACGGCTATGAGAATATTAA TTCGAATAGAATTAGGACAGGTAGGAAGTT TTTTAGGAAGTGATCATTTGTATAATGTAAT TGTTACTGCTCATGCATTTGTAATGATTTTT TTTATAGTTATGCCTATTTTGATTGGAGGAT TTGGAAATTGATTAGTTCCCTTAATACTTGG TGCTCCTGATATGGCTTTTCCTCGAATAAAT AATTTAAGATTTTGATTGTTACCTCCTTCTT TATTATTATTATTTATTTCGTCTATGGCTGA AATAGGAGTAGGTGCTGGATGAACTGTATA TCCTCCTTTAGCATCTATTGTTGGTCACAAT GGAAGCTCTGTAGATTTTGCTATTTTTTCTT TACATTTAGCGGGTGCTTCTTCTATTATAGG GGCTATTAATTTTATTTCTACAATTATTAAT
ATGCGTTCAGTAAATATATCTATAGATAAAG TTTCGTTATTTGTATGATCTGTAATGATTAC AGCTGTTCTTTTATTATTATCTTTACCTGTT TTAGCAGGTGCTATTACTATATTATTAACTG ATCGAAATTTTAATACATCTTTTTTTGATCC TGCTGGAGGAGGGGATCCTATTTTGTTTCA ACATTTATTT

Wedoquella karadya Rubio, Baigorria \& Edwards, sp. nov.

(Figs. 1D-F; 2D-H; 4)

Type material. Male holotype (IBSI-Ara 0802) from Argentina, Misiones: Karadya BioReserve (S25.859 ${ }^{\circ}$, W53.961 ${ }^{\circ}$ ), 07 October 2015, J.E. Baigorria coll. Paratypes: 1 male (IBSI-Ara 0874; tiss.s. 0874), same locality and collector, 02 November 2016; 1 female (IBSI-Ara 0910) from Misiones: Parque Nacional Iguazú, Apepú station (S25.564 $\left.{ }^{\circ}, \mathrm{W} 54.296^{\circ}\right), 03$ November 2016, M. Cavicchia coll.

Etymology. The specific name is a noun in apposition that refers to the type locality: Karadya Bio-Reserve.

Diagnosis. Specimens of $W$. karadya are more similar to those of $W$. apnnea (see previous 

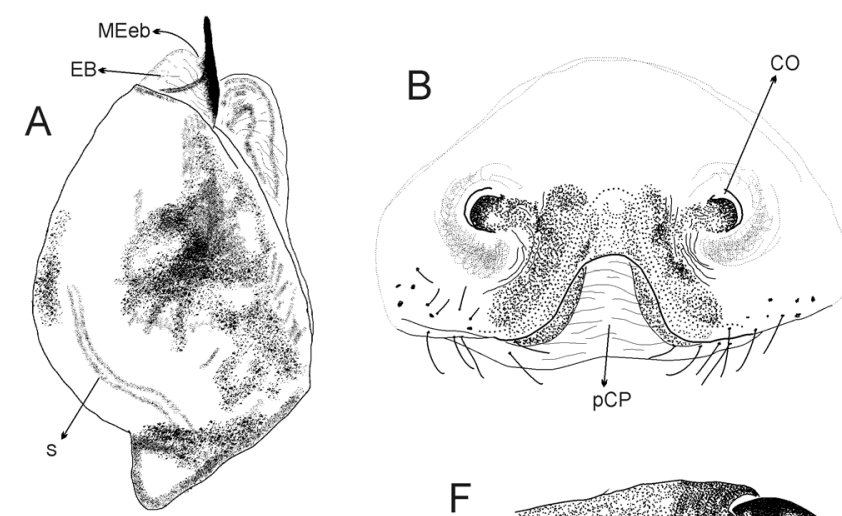

$\mathrm{F}$

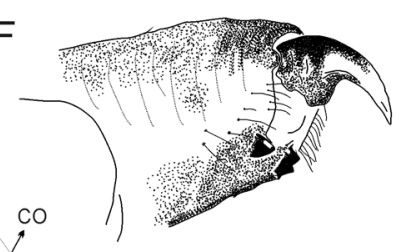

D
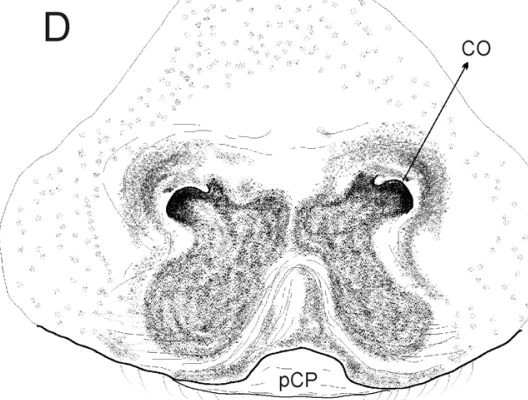
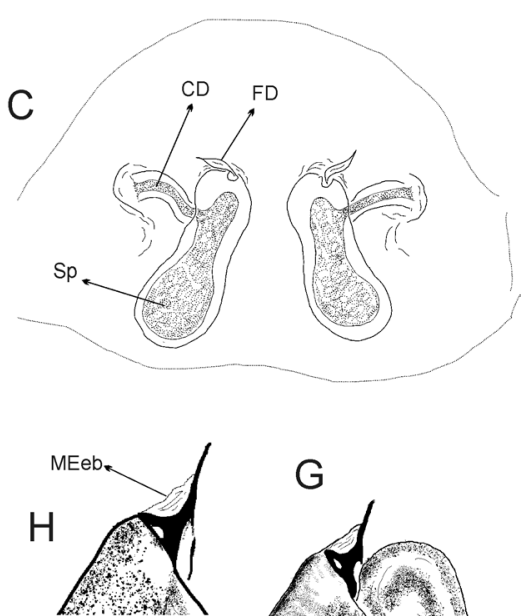

G

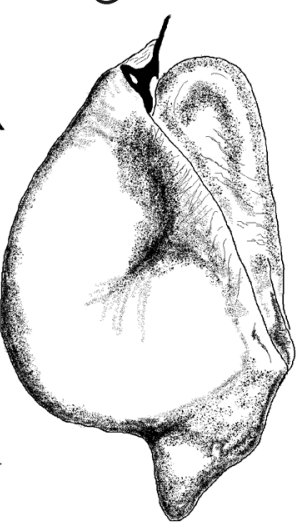

Fig. 2. Wedoquella apnnea sp. nov. (A-C) and W. karadya sp. nov. (D-H). Male copulatory bulb, ventral (A, G); female cleared epigyne, ventral (B, D) and dorsal (C, E); female right chelicera, posterior (F); detail of male embolus, ventral $(\mathrm{H})$.

diagnosis). Male of W. karadya can be easily distinguished from that of $W$. apnnea by having a triangular-shaped RTA, with a wide base (Fig. $4 \mathrm{~B}, \mathrm{C}, \mathrm{E})$, and a prominent membranous part (MEeb) of the EB (Figs. 2G, H; 4D). Female of W. karadya is distinguished from W. apnnea by having narrower and deeper pCP, and spermathecae slightly closer to each other (Figs. 2D, E; compare with $2 \mathrm{~B}, \mathrm{C}$ ).

Description. Illustrated in figures 1D, E; 2G, $\mathrm{H}$; 4A-D: male (holotype): total length: 9.90 (paratype 9.10). Carapace length: 4.80; width: 3.85. The pattern and coloration is similar to that of the $W$. apnnea, except for a slender projection of the white carapace marginal band towards the posterior dorsal side of the carapace, below the posterior lateral eyes (Figs. 1E; 4A). Chelicerae black, teeth as in W. apnnea. Sternum and legs as in W. apnnea. Abdomen length: 5.05; width: 3.70 ; coloration of abdomen as in W. apnnea. Live specimens have strong coloration but do not have the eyes bordered by red scales. Palp: femur stout, tibia wider than long with conspicuous sclerotized triangular-shaped RTA, with a wide base. Embolus short, straight, well-sclerotized, associated with a small membrane on the distal prolateral edge of the embolus base. Cymbium with proximal dorsal projection.

Female (paratype) illustrated in figures $1 \mathrm{~F}$; 2D-F; 4I-L: total length: 10.37. Carapace length: 5.00; width: 4.00. Abdomen length: 5.30; width: 4.10. The rest of the description of the female is as that of W. apnnea. Note: right leg IV is broken from the patella.

Natural History. Males of W. karadya were collected on a railing of an elevated wooden walkway located within an Atlantic Forest environment. The spiders look somehow "flat" with extended legs and body close to the substrate. They move fast, and immediately look for shelter in human presence. One of the individuals was feeding on a caterpillar (Lepidoptera). It is noteworthy that an additional specimen with similar pattern to the apnnea group females observed on the same railing was also feeding on a caterpillar. Unfortunately, we could not collect 

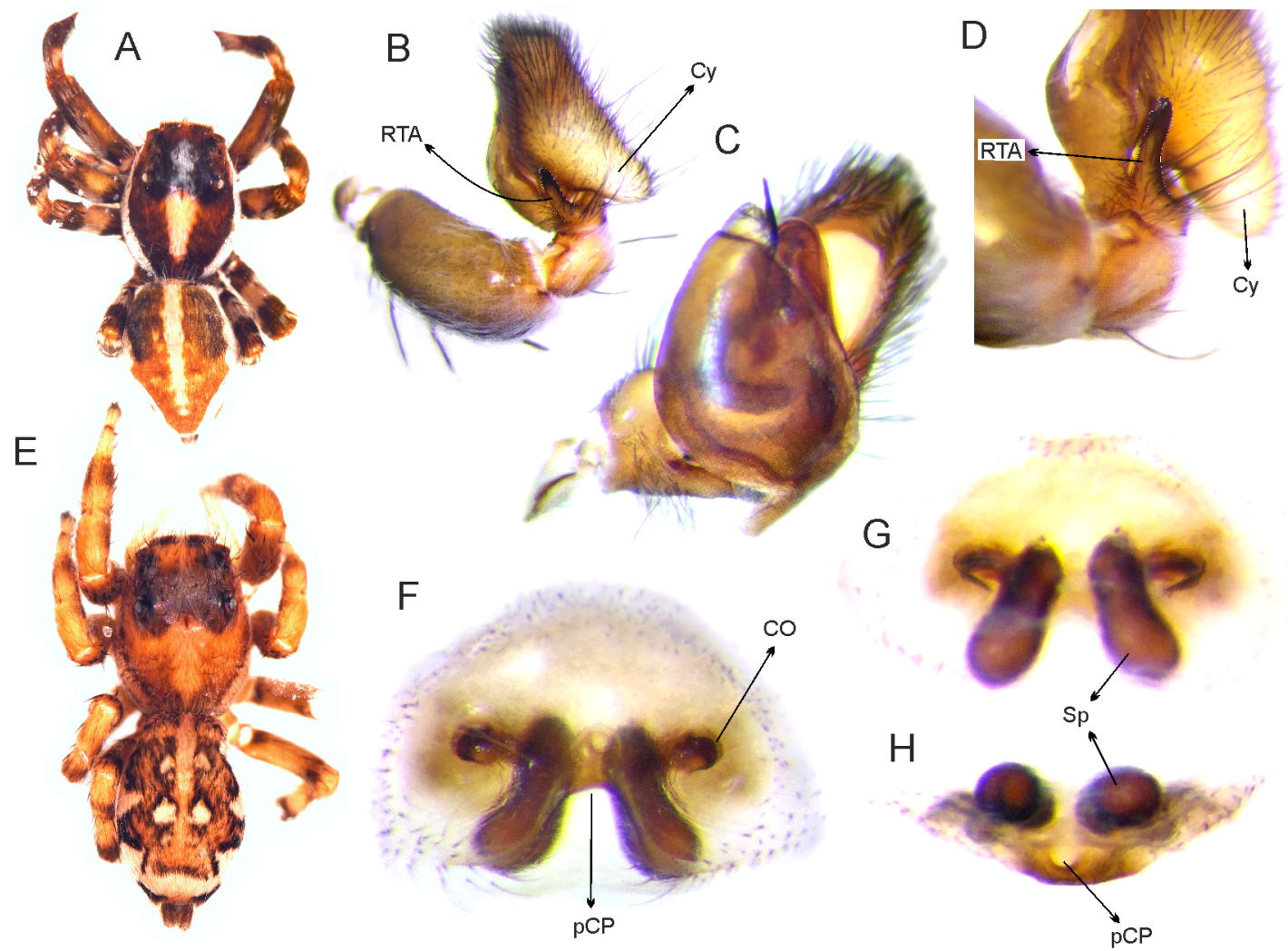

Fig. 3. Wedoquella apnnea sp. nov. Male (A-D) and females (E-H); habitus, dorsal (A, E); left palp, retrolateral (B); copulatory bulb, ventral (C); detail of RTA (D). Cleared epigyne, ventral (F), dorsal (G) and posterior (H).

this spider to confirm its species identity but according to the pattern of coloration and the location could be W. karadya.

Distribution. Only known from northeast Argentina, in Misiones province.

Barcode. Nucleotide sequence of COI-5P of male paratype, process ID IBSAR077-17:

AACTTTATATTTAATTTTTGGAGCTTGATCT GCTATAGTTGGAACGGCTATGAGAATATTAA TTCGAATAGAATTAGGACAGGTAGGAAGTT TTTTAGGGAGTGATCATTTGTATAATGTAAT TGTTACTGCTCATGCATTTGTAATAATTTTT TTTATAGTTATGCCTATTTTGATTGGAGGTT TTGGAAATTGATTAGTTCCTTTAATACTTGG TGCTCCTGATATGGCTTTTCCTCGAATAAAT AATTTAAGATTTTGATTGTTACCTCCTTCTT TATTATTATTATTTATTTCATCTATGGCTGA AATAGGAGTGGGTGCTGGATGAACTGTTTA TCCTCCTTTAGCATCCATTGTTGGTCACAAT GGAAGTTCTGTAGATTTTGCTATTTTTTCTT TACATTTAGCGGGTGCTTCTTCTATTATAGG GGCTATCAATTTTATTTCTACAATTATTAAT ATGCGTTCAGTAAATATATCTATAGATAAAA
TTTCTTTATTTGTATGATCTGTAATGATTAC AGCTGTTCTTTTATTATTATCTTTACCTGTT TTAGCAGGTGCTATTACTATATTATTAACTG ATCGAAATTTTAATACATCTTTTTTTGATCC TGCTGGAGGAGGGGATCCTATTTTGTTTCA ACATTTATTT

\section{DNA analysis results}

Both trees (NJ and ML) had identical results, showing two well defined groups of Simonellini plus Sarindini spiders (or Euophrinyi, not shown) forming one clade, and another clade including all the spiders listed within the Aelurillini tribe according to Maddison (2015), see figure 5. The species described in this manuscript are grouped together with other Wedoquella species in both trees, forming a well-defined subgroup. The male from Misiones (IBSI-Ara 0874, W. karadya) differs from the other two individuals, reinforcing the proposed species. On the other hand, the COI analyzed fragment in female and male of $W$. apnnea confirms the conspecificity. 

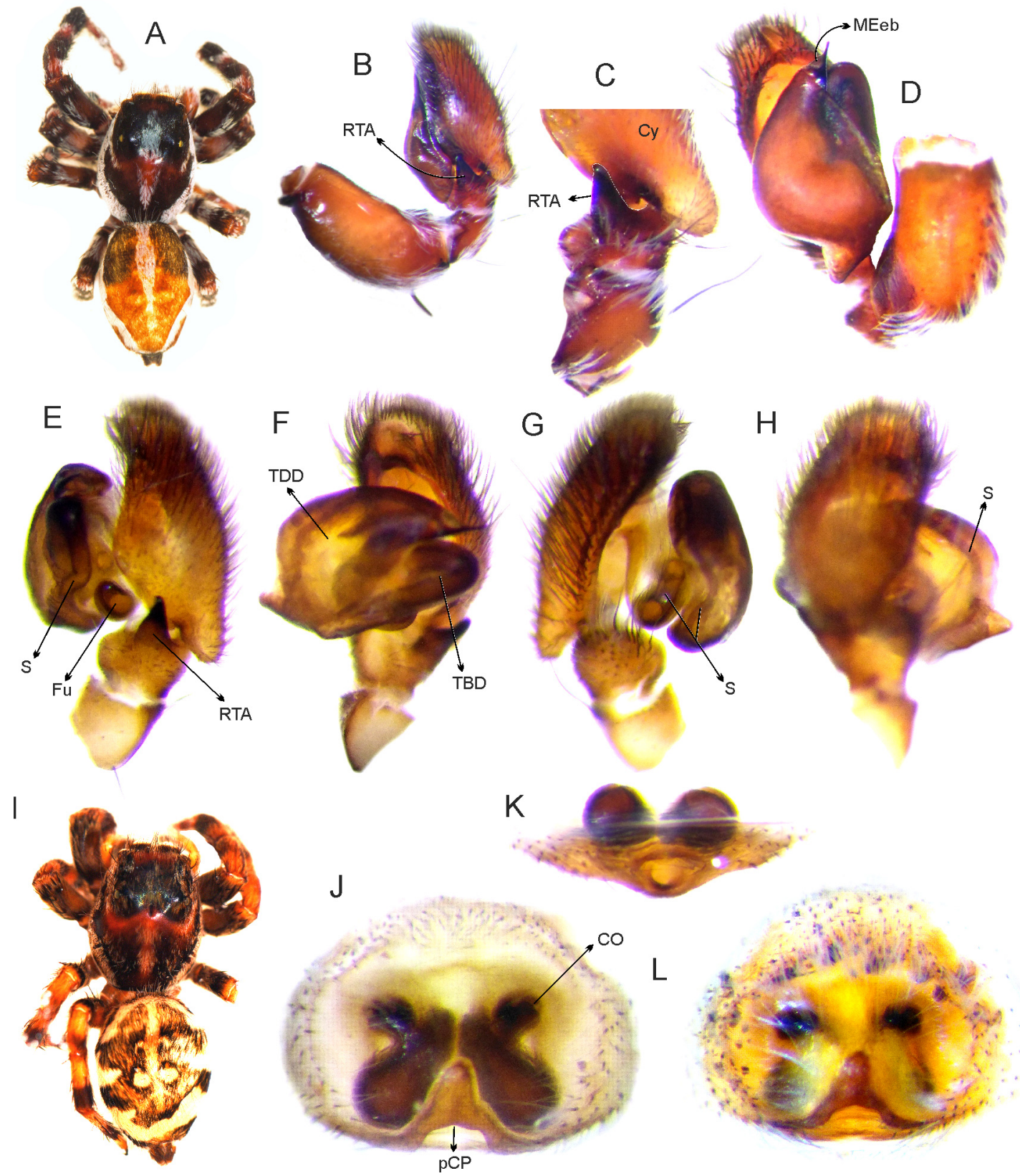

Fig. 4. Wedoquella karadya sp. nov. Male (A-H) and females (I-L); habitus, dorsal (A, I); left palp, retrolateral (B); detail of RTA (C); copulatory bulb, ventral (D); expanded left palp, retrolateral (E), ventral (F), prolateral $(\mathrm{G})$ and dorsal $(\mathrm{H})$ views. Cleared epigyne, ventral $(\mathrm{J})$, posterior $(\mathrm{K})$, and ventral, not cleared $(\mathrm{L})$.

\section{DISCUSSION}

The two species of Wedoquella herein described are very similar in habitus (morphology and coloration) to those of the Phiale gratiosa group. Males of Phiale are distinguished from other Freyina by having a moderately long but not slender embolus, a transverse tegulum distal division (TDD) with a proximal retrolateral lobe at a right angle, and the area of proximal prolateral lobe of TDD truncate; females have copulatory openings with an extended outer edge forming secondary atria within a larger atrium (Edwards 2015). Three species groups were 


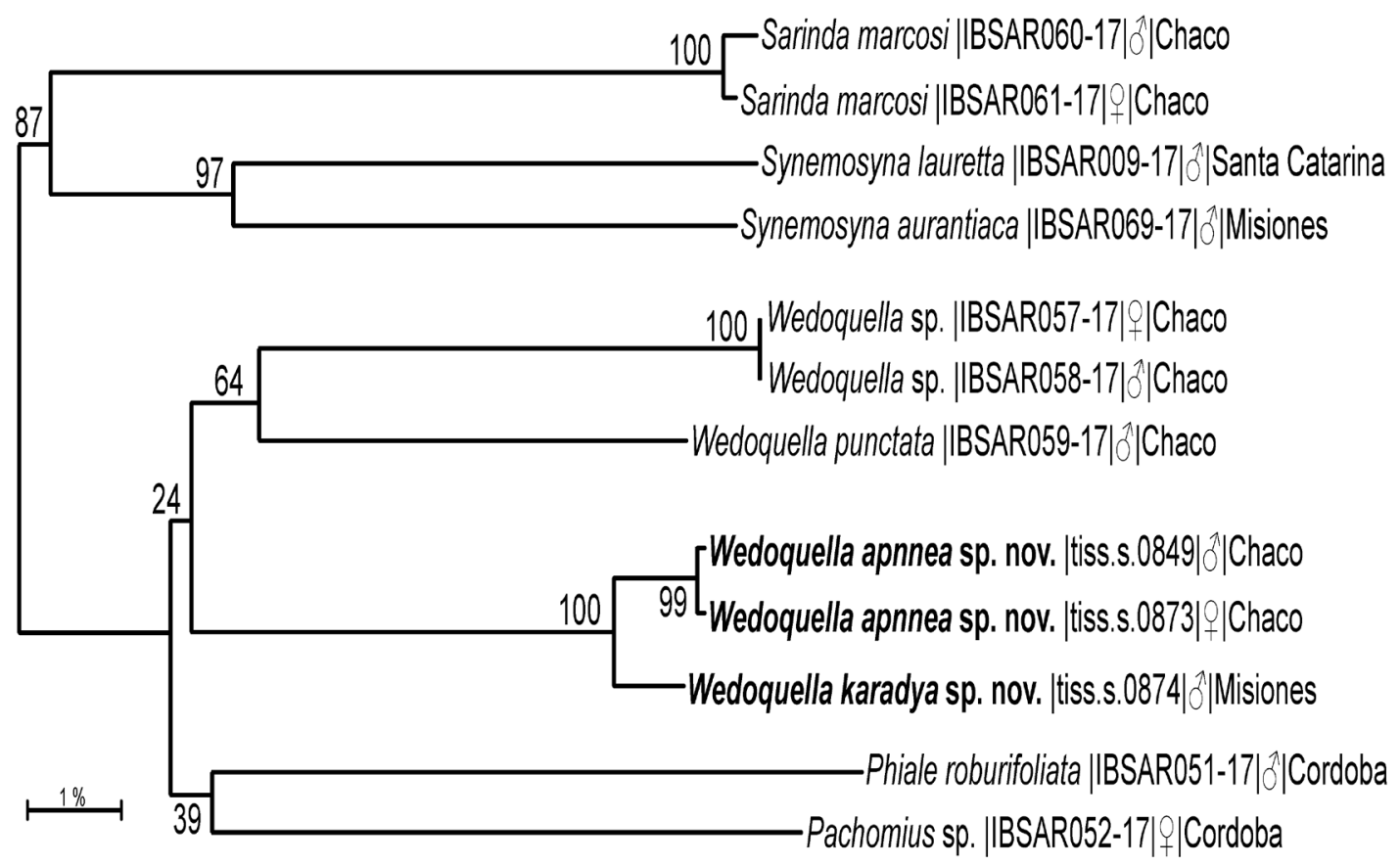

Fig. 5. Taxonomic identification tree of barcode sequences of some jumping spiders including the two Wedoquella spp. described herein and other freyines species, based on molecular data (Maximum Likelihood).

previously designated, the gratiosa and mimica groups by Galiano (1981a, b), and the formosa group by Edwards (2015).

However, the genitalia of these Wedoquella species is different from any species of Phiale, except for some structures shared by both (e.g., a proximal retrolateral lobe extending from a transverse tegulum). The embolus is shorter with a wider base, and the copulatory openings of the female epigyne are far apart and not contained within a large atrium. The genital structures are quite similar to the species of Wedoquella, except for the embolus base which is partly membranous distally, forming an edge (MEeb). This could be an incipient lateral subterminal apophysis (LSA), but it is not separated from the embolus as in Pachomius. The epigyne of the female described in this manuscript also has some similarity to $W$. macrothecata Galiano, 1984 in the placement of the copulatory openings and the enlarged spermathecae. As Wedoquella and Phiale are thought to be close relatives (Edwards 2015), it is not surprising that additional somatic similarities between them have been found, yet the genitalic distinctiveness of the two genera has been maintained. It is noteworthy that the new species group lacks the unique extra tibial apophysis found in previously known species of Wedoquella.
Although the low support of our nodes of the gene tree based on the COI sequences (Fig. 5) raises some doubts about them, and that Zhang and Maddison (2013) point out that the inference of evolutionary relationships with COI in Salticidae has many problems. Although members of the same genus can be separated in our trees only based on this fragment, both our morphological and genetic analysis showed the same result, suggesting that the two species could be more related to Wedoquella than to Phiale. However, there are other possibilities to consider. Given the close resemblance to some members of the Phiale gratiosa group, it is possible that these species are indeed Phiale, but that would necessitate a number of major changes. First would be a radical redefinition of Phiale, as the genital structures of the apnnea group and Wedoquella are distinctly different from that of Phiale. Second, it would be necessary to synonymize Wedoquella with Phiale. Another option would be to describe a new genus for the two species of the apnnea group since they do possess a distinctive cymbial structure only present in a distantly related freyine genus, Philira. Given the limited molecular data presented here, and the close relationship of the included genera, we consider the best option is to place the species in the genus to which they show the closest molecular and genitalic similarity. 


\section{ACKNOWLEDGEMENTS}

We thank Eric Stolar (INTA) for the collected material and the ecological observations on $W$. apnnea; the editor Andrés Ojanguren (MACN) for helpful comments and corrections on the final manuscript. The Administración de Parques Nacionales (APN) issued permits for collecting; we wish to thank especially Marcelo Cavicchia and Andrés Bosso, as well as Gillermo Gil of the Centro de Investigaciones Ecológicas Subtropicales (CIES) for logistic support. We also wish to thank, in particular, the authorities of the Chaco and Iguazú National Parks for its hospitality and lodging. This publication is funded by the "Fondo para la Investigación Científica y Tecnológica" (FONCyT): grant PICT-2013-1664 given to GDR.

\section{REFERENCES}

Edgar, R.C. 2004. MUSCLE: multiple sequence alignment with high accuracy and high throughput. Nucleic Acids Research 32: 1792-1797. pmid: 15034147

Edwards, G.B. 2015. Freyinae, a major new subfamily of Neotropical jumping spiders (Araneae: Salticidae). Zootaxa 4036(1): 1-87. doi.org/10.11646/ zootaxa.4036.1.1

Felsenstein, J. 1985. Confidence limits on phylogenies: An approach using the bootstrap. Evolution 39: 783-791.

Folmer, O., Hoeh, W.R., Black, M.B. \& R.C. Vrijenhoek. 1994. Conserved primers for PCR amplification of mitochondrial DNA from different invertebrate phyla. Molecular Marine Biology and Biotechnology 3: 294-299.

Galiano, M.E. 1981a. Revisión del genero Phiale C. L. Koch, 1846 (Araneae, Salticidae) III. Las especies polimórficas del grupo mimica. Journal of Arachnology 9: 61-85.

Galiano, M.E. 1981b. Revision of the genus Phiale C. L. Koch, 1846 (Araneae, Salticidae). IV. The polymor- phic species of the gratiosa group. Bulletin of the British Arachnological Society 5: 205-216.

Galiano, M.E. 1984. Descripción de Wedoquella nuevo género (Araneae, Salticidae). Journal of Arachnology 11: 343-352.

Ivanova, N.V., Dewaard, J.R. \& P.D.N. Hebert. 2006. An inexpensive automation-friendly protocol for recovering high-quality DNA. Molecular Ecology Notes 6(4): 998-1002.

Kimura, M. 1980. A simple method for estimating evolutionary rate of base substitutions through comparative studies of nucleotide sequences. Journal of Molecular Evolution 16: 111-120.

Kumar, S., Stecher, G., Li, M., Knyaz, C. \& K. Tamura. 2018. MEGA X: Molecular Evolutionary Genetics Analysis across computing platforms. Molecular Biology and Evolution 35: 1547-1549.

Levi, H.W. 1965. Techniques for the study of spider genitalia. Psyche 72: 152-158.

Maddison, W.P. 2015. A phylogenetic classification of jumping spiders (Araneae: Salticidae). Journal of Arachnology 43(3): 231-292. doi.org/10.1636/arac43-03-231-292

Metzner, H. 2019. Jumping spiders (Arachnida: Araneae: Salticidae) of the world. Online at: https://www. jumping-spiders.com (accessed on 18 June 2019).

Saitou, N. \& M. Nei. 1987. The neighbor-joining method: A new method for reconstructing phylogenetic trees. Molecular Biology and Evolution 4: 406-425.

Tamura, K. \& M. Nei. 1993. Estimation of the number of nucleotide substitutions in the control region of mitochondrial DNA in humans and chimpanzees. Molecular Biology and Evolution 10: 512-526.

Wilson, J.J. 2012. DNA barcodes for insects. In Kress W.J. \& D.L. Erickson (eds.). DNA barcodes: Methods and protocols, pp. 17-46, Springer.

World Spider Catalog. 2019. World Spider Catalog. Version 20.0. Natural History Museum Bern, online at: http://wsc.nmbe.ch (accessed on 18 June 2019). doi: $10.24436 / 2$

Zhang, J.X. \& W. P. Maddison. 2013. Molecular phylogeny, divergence times and biogeography of spiders of the subfamily Euophryinae (Araneae: Salticidae). Molecular Phylogenetics and Evolution 68: 81-92. doi:10.1016/j.ympev.2013.03.017

Doi: 10.22179/REVMACN.21.639

Recibido: 10-V-2019

Aceptado: 25-VI-2019 